\title{
Ethics and Its Relations With Education and Research*
}

\author{
Alex Egido \\ State University of Londrina, Londrina, Brazil
}

\begin{abstract}
Brazilian studies in (Critical) Applied Linguistics' field have being carried out focusing on ethics. They focused on the relation between ethics and two main contexts: education and research. This paper aims at discussing what ethical procedures were taken in international studies. The data were collected at ERIC (Educational Resources Information Centre) database during the first semester of 2016. As analytical categories, we used the ethical procedures established by Brazilian Applied Linguists. The contribution is addressed to both BAL and International Applied Linguists once it offers an overview about a specific topic of research (viz., ethics). As results, we observed that most of the topics presented by the Brazilian applied linguists were also covered by the research analyses. However, the social relevance was not reported properly by the data and that may be improved.
\end{abstract}

Keywords: Critical Applied Linguistics, research, ethics

\section{Introduction}

Brazilian investigations in the (Critical) Applied Linguistics' (Pennycook, 2001) field have being done focusing on ethics. Both prescriptive (Celani, 2005; Menezes de Souza, 2011; Miller, 2010, 2013; Paiva, 2005) and prospective (Egido \& Reis, 2015; Reis, Egido, Silva, Coradim, \& D’Almas, 2016; Reis \& Egido, in press) are characteristics of those studies. They focused on the relation between ethics and two main contexts: education and research.

This paper aims at discussing what ethical procedures were taken in international studies. The data were collected at ERIC (Educational Resources Information Centre) database during the first semester of 2016. In order to do so, we used the terms "Ethics and Applied Linguistics", "Ethics and Critical Applied Linguistics", "Ethics and Emancipation", and "Ethics and Second Language Education", totalizing 30 works. As analytical categories, we used the procedures established by Brazilian Applied Linguists (BAL) that will be discussed on the next section.

This paper contributes to both BAL and International Applied Linguists once it offers an overview about a specific topic of research (viz., ethics).

\section{Theoretical Framework}

Brazilian Applied Linguists have focused on ethics and its relations with education (e.g., Menezes de Souza, 2011; Mello, 2010), research (e.g., Egido \& Reis, 2015; Moita Lopes, 2006; Paiva, 2005; Reis et al., 2016; Reis

\footnotetext{
* Acknowledgements: I would like to thank Professor Simone Reis, my advisor, at State University of Londrina. Alex Egido, researcher, undergraduate, Modern Foreign Languages, State University of Londrina, Brazil.
} 
\& Egido, in press) or both (e.g., Celani, 2005; Miller, 2013). In this section, we are going to take into account Brazilian studies.

\section{Ethics and Education}

Menezes de Souza (2011), professor at University of São Paulo, discussed the social roles of foreign language teachers. According to him, teachers ought to go further than just discuss teaching-learning methods. This topic (viz., teaching-learning methods) is relevant, but 21 st century educators need to wonder how much contexts may influence the classrooms. In other words, considering the implications of a globalized world into the classrooms is a teachers' "ethical responsibility" (Menezes de Souza, 2011, p. 286). Similar to Menezes de Souza's (2011) considerations, Miller (2013) argued that in order to have a teacher that works ethically and critically, the University needs to provide him/her a high-level education in both undergraduate and graduate levels.

When the ethical education turns to the graduate programs, Celani (2005) focused on the relation between the new researcher and his/her advisor. She explained that an advisor has the social and ethical role of advising the new researcher in terms of what to do during the conduction of an investigation and how to do it. It is the advisor's role that teaches the new researcher how to behave ethically in the academic context.

In summary, the ethics is important for both educational contexts, basic school (Menezes de Souza, 2011) and academic field (Celani, 2005; Miller, 2013).

\section{Ethics and Research}

When Brazilian researchers focus on ethics in an on-going investigation, they often consider ethical procedures that should be taken by the work's proponent. By this, we can understand: (1) getting the consent from the participants; (2) anonymity; (3) consider the asymmetry between social roles (i.e., researcher and participants); and (4) the investigation's relevance, and others procedures that will discussed further in this section.

In her secondary-base study, Celani (2005) discussed what she called ethical questions. According to this author, relations of power permeate research studies developed in Applied Linguistics field. She argued that while developing a study, the researcher has to be aware of getting the consent from the participants, how the on-going investigation is going to contribute to the social context where the participants live, and the risks and benefits of the work. Celani (2005) believes that the Applied Linguistic researcher should aim at developing a survey in which the participants are empowered (Cameron, Frazer, Harvey, Rampton, \& Richardson, 1994). In order to do so, dialogical procedures should be taken, for instance, returning the analysis for the participants, giving them the opportunity to react, and its relevance to them. Similar to the previous study, Paiva (2005) discussed ethical dilemmas for researchers. The same ethical procedures presented by Celani (2005) were mentioned in Paiva's work.

Moita Lopes (2006), a well-known Brazilian Applied Linguist, aimed at problematizing the constructs for research. He defends researchers have to hear the voices of minority groups in order to be aware of their needs and, then, to develop an investigation with social relevance for the participants. According to him, applied linguists ought to "reinvent the ways to produce knowledge" (Moita Lopes, 2006, p. 83). In other words, participants add to the investigation somehow, ${ }^{1}$ then, researchers do not have all the "power" to conduct the study. The author also reported the importance of applying an ethical agenda for research in Applied Linguistics'

\footnotetext{
${ }^{1}$ Miller (2010) and Mello (2010) called it as collaborative work. We are going to present how participants can work with researchers in the following sections of this paper.
} 
and Social Sciences' fields. Miller's paper (2010) converged on the ideas presented so far in terms of research. She contributed to this discussion once that she highlighted these ethical aspects in a specific perspective (i.e., Exploratory Practice).

Consent, anonymity, feedback for the participants, and dialogism are characteristics of an emancipatory ethics (Cameron et al., 1994). These ethical procedures were highlighted on Egido and Reis' (2015) analysis that was based on an inductive-deductive method. Their objective was to understand the ethical procedures adopted by thesis and dissertations that have focused on critical reading and critical literacy. In short, the proponents of those studies had a dialogical stance and tried to reduce the power's symmetry between researcher and participants.

Reis et al.'s (2016) study is an example of what has been changed in terms of ethical procedures in Applied Linguistics filed. They aimed at presenting a descriptive view of Critical Applied Linguistics. In order to do so, the authors sent a questionnaire to International Congress of Critical Applied Linguistics ${ }^{2}$ participants that had had a proposal presentation approved by the ICCAL Scientific Committee. The volunteer participants were asked to answer 20 topics. One of them was regarding the ethics adopted in their researches. This topic specifically presented that the major number of studies in Applied Linguistics (50\%) adopted the formal ethics (Christians, 2005). However, other participants mentioned that they had used dialogical procedures (viz., their participants' voices (12\%) and feedback of the results (17\%)). Based on these findings, we affirm that despite the formal ethics (Christians, 2005) is still strong in applied linguistics' investigations, many researches (29\%) empowered their participants (Cameron et al., 1994), giving them opportunity to react.

In summary, all the investigations mentioned in this section defended an emancipatory ethics (Cameron et al., 1994) instead of a formal one (Christians, 2005).

\section{Methodological Procedures and Data's Characteristics}

This mapping resulted from the collection of research studies in ERIC (Educational Resources Information Centre) database during the 2016 first semester.

The synoptic representation below shows the terms that we used and how many works were found. As criteria, we decided to narrow the searches on "peer reviewed only" and "full text on ERIC".

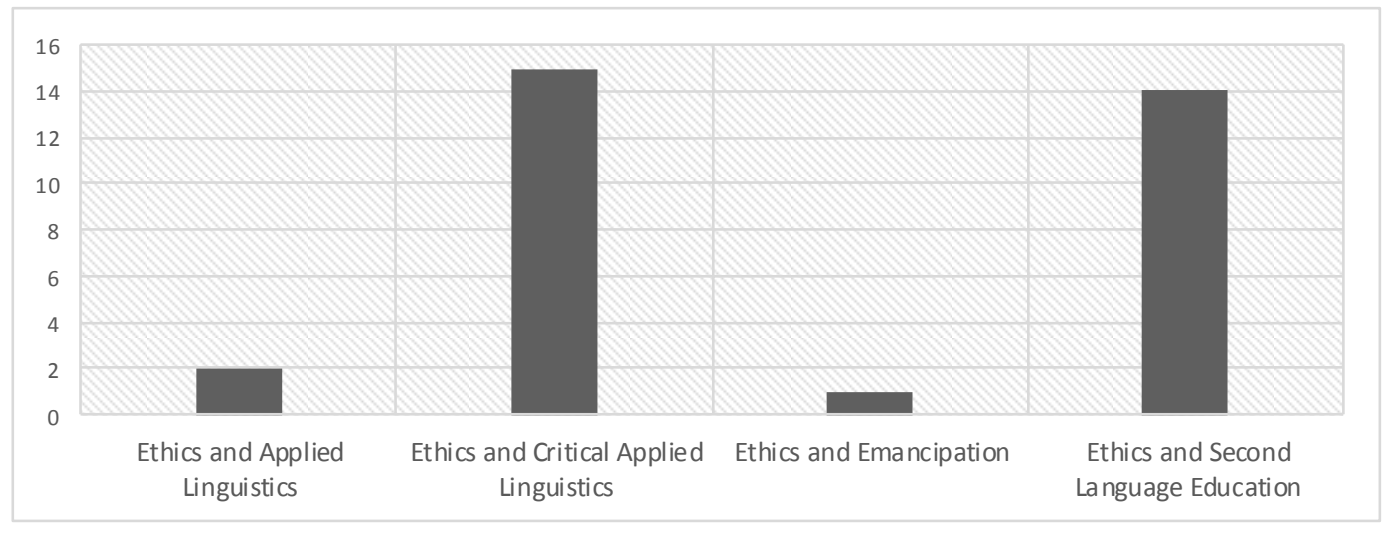

Figure 1. Representation of the terms reached and result.

\footnotetext{
${ }^{2}$ http://www.uel.br/projetos/iccal/
} 
Using "Ethics and Applied Linguistics", we localized two studies (viz., Goldacre, Bolt, \& Lambiris, 2013; Kim, 2008). Using "Ethics and Critical and Applied Linguistics", we found 15 researches (viz., Abrams, 2005; Angel \& Simpson, 2007; Arnett \& Mady, 2010; Davari, Iranmehr, \& Erafni, 2012; Derrington \& Larsen, 2009; Goldacre, Bolt, \& Lambiris, 2013; Guardado, 2012; Jin, 2011; Mossman, 2012; Sánchez, 2007; Shinn, Briers, \& Baker, 2008; Swain \& Lapkin, 2011; Welch, Hieb, \& Graham, 2015; Wernicke, 2010; Zhao, 2014). The term "Ethics and emancipatory" had just one paper (viz., Scalia \& Scalia, 2011). When we applied "Ethics and Second Language Education", we localized 14 studies (viz., Abasi \& Taylor, 2007; Ekahitanond, 2014; Fong \& Tanaka, 2014; Green, Lindemann, Marshall, \& Wilkinson, 2005; Howie, 2008; Khan, 2011; Koulouriotis, 2011; Lee, 2011; Loi, 2010; MacPherson \& Kouritzin, 2005; Toprak et al, 2010; Goldacre, Bolt, \& Lambiris, 2013; White \& Heberling, 2006; Hodge \& Lear, 2011).

After downloading all the papers, we noticed that one of them (viz., Goldacre, Bolt, \& Lambiris, 2013) occurred on three searches (viz., Ethics and Applied Linguistics, Ethics and Critical Applied Linguistics, and Ethics and Second Language Education). Therefore, we are going to analyse 30 studies, actually, instead of 32.

In the first classification done, we divided the studies in (1) (Critical) Applied Linguistics or (2) other areas. After that, we analysed whether the research works mentioned the application of ethical procedures or not. See the table below.

Table 1

Occurrence of Ethics in (Critical) Applied Linguistics' and Other Areas' Research Works

\begin{tabular}{|c|c|c|c|}
\hline \multicolumn{2}{|l|}{ (Critical) Applied Linguistics } & \multicolumn{2}{|l|}{ Other áreas } \\
\hline \multicolumn{2}{|l|}{ Ethical procedures } & \multicolumn{2}{|l|}{ Ethical procedures } \\
\hline Mentioned & Not mentioned & Mentioned & Not mentioned \\
\hline $\begin{array}{l}\text { Abasi and Taylor (2007); } \\
\text { Abrams (2005); } \\
\text { Davari, Iranmehr, and Erfani (2012); } \\
\text { Fong and Tanaka (2013); } \\
\text { Howie (2008); } \\
\text { Koulouriotis (2011); } \\
\text { Lee (2011); } \\
\text { Ekahitanond (2014); } \\
\text { Loi and McDermott (2010); } \\
\text { Macpherson, Kouritzin, and Kim (2005); } \\
\text { Mossman (2012); } \\
\text { Swain and Lapkin (2011); } \\
\text { Wernicke (2010); } \\
\text { White and Haberling (2006); } \\
\text { Green et al. (2005). }\end{array}$ & $\begin{array}{l}\text { Arnett and Mady (2010); } \\
\text { Guardado (2012); } \\
\text { Jin (2011); } \\
\text { Khan (2011); } \\
\text { Sánches (2007). }\end{array}$ & $\begin{array}{l}\text { Angel and Simpson (2007); } \\
\text { Goldacre, Bolt, and Lambiris } \\
\text { (2013); } \\
\text { Kim (2008); } \\
\text { Shinn, Briers, and Baker (2008); } \\
\text { Toprak et al. (2010); } \\
\text { Welch, Hieb, and Graham } \\
\text { (2015); } \\
\text { Zhao (2014). }\end{array}$ & $\begin{array}{l}\text { Scalia and Scalia (2011); } \\
\text { Hodge and Lear (2011); } \\
\text { Derrington and Larsen } \\
(2009) \text {. }\end{array}$ \\
\hline
\end{tabular}

Based on Table 1, we can say that half of the studies (15 out of 30) belongs to (Critical) Applied Linguistics area and adopt any ethical procedure. These are the studies that we will focus on later on.

\section{Results}

Most of the studies are characterized as primary investigations (viz., Abasi \& Taylor, 2007; Abrams, 2005; Davari, Iranmehr, \& Erfani, 2012; Ekahitanond, 2014; Green et al., 2005; Koulouriotis, 2011; Lee, 2011; Mossman, 2012; Swain \& Lapkin, 2011; Wernicke, 2010; White \& Haberling, 2006). 


\section{Informed Consent}

This category was discussed for BAL as presented in the theoretical framework section. When it turns to the papers analysed, six of them (Abasi \& Taylor, 2007; Ekahitanon, 2014; Green et al., 2005; Koulouriotis, 2011; Lee, 2011; Loi \& McDermott, 2010) applied (or mentioned) this ethical procedure.

We assume that the researchers whose papers are focused here applied the informed consent in different ways. Koulouriotis (2011) explained that she contacted three researchers who have developed some research with no native English speakers at a Canadian University. With the invitation to take part in her investigation, she explained the nature of the study. Differently from Koulouriotis (2011), Ekahitanond (2014) sent a written consent to all 160 students.

In her case study, Lee (2011) carried out a research in a school with teachers, administrators, and students. The research provided informed consent to all of them. In the paper, she explained the ethical dilemmas that took place with one teacher during her ongoing investigation. Abasi and Taylor (2007) provided the informed consent to teacher and her students. Green et al. (2005) did not observe that the informed consent was applied, but that "survey completion was not compulsory" (Green et al., 2010, p. 27).

Differently from the previous research studies, Loi and McDermott (2010) discussed in their theoretical paper some ethical procedures that ought to be applied in an ongoing research. Informed consent is one of them. The authors explained what should be considered in this document in order to participants be actually confident about the study. They conclude saying that,

Evaluators should always strive to use an informed consent process when possible. Situations may arise when a signed informed consent is not feasible. Moreover, recording a person's name may not be necessary. Finding creative ways to collect an informed consent form while protecting an individual's identity may be a viable option, such as using identifiers that only the participant would recognize. (Loi \& McDermott, 2010, p. 255)

In synthesis, the researchers applied the informed consent by E-mail (e.g., Koulouriotis, 2011) or written (e.g., Ekahitanond, 2014). Despite that, other researchers did not mention how they got the consent (e.g., Abasi \& Taylor, 2007; Lee, 2011). It is important to say that no study reported if they applied any special dialog with participants based on their characteristics in order to explain the informed consent.

\section{Anonymity}

The anonymity was applied in 10 studies (viz., Abasi \& Taylor, 2007; Abrams, 2005; Ekahitanond, 2014; Green et al., 2005; Koulouriotis, 2011; Lee, 2011; Mossman, 2012; Swain \& Lapkin, 2011; Wernicke, 2010; White \& Haberling, 2006).

Considering these works, their participants were referred in three different ways, for instance, pseudonyms (viz., Lee, 2011; Mossman, 2012; Swain \& Lapkin, 2011; White \& Haberling, 2006), codes (viz., Abrams, 2005; Ekahitanond, 2014; Green et al., 2005), or named as participants (viz., Abasi \& Taylor, 2007; Koulouriotis, 2011; Wernicke, 2010).

In sum, the difference between the use of codes and pseudonyms/participants is regarded to the number of participants. In other words, the investigations that used codes to refer to their participants have probably done that considering the number of people involved (viz., hundred). Nevertheless, it does not matter what is applied, whether pseudonyms or codes; the main objective is to guarantee the anonymity to the participants. 


\section{Feedback to the Participants}

This ethical procedure, which gives opportunity to participants' reaction, happened in Abasi and Taylor (2007) and Koulouriotis (2011). Abasi and Taylor (2007) discussed the use of video as a way to collect data in the classrooms. The authors provided instances by a research carried out by them. They explained that instead of having applied the informed consent before the investigation beginning, it is important as well giving participants the opportunity to refuse the analysis they had done. Considering the use of video in the classrooms, it is almost impossible to guarantee the anonymity, said the authors.

Similar to Abasi and Taylor (2007), Koulouriotis (2011) gave the participants a feedback of her analysis and also discussed its importance. Regarding to this ethical posture, she mentioned that "[...] researchers continually scrutinize their own practices, acknowledging that ethics is the responsibility of the individual researcher and that ethical conduct is a continual, ongoing process" (Koulouriotis, 2011, p. 14).

\section{Dialogism}

Some researchers reported their worries about the asymmetry of power between them and their participants (viz., Abasi \& Taylor, 2007; Loi \& McDermott, 2010; Mossman, 2012; Swain \& Lapkin, 2011).

Koulouriotis (2011) took another ethical procedure which gives voice to participants. She made the full transcript of interviews available to them. According to her, the English proficiency can be one asymmetrical characteristic between native speakers (researchers) and their participants (non native speakers).

Loi and McDermott (2010) also commented about final reports. According to them, researchers ought to "consider the impact and ethical implication this reporting will have on the participants and programs" (Loi \& McDermott, 2010, p. 255).

In general, we assume that the return of analysis to the participants is one of the most important procedures in order to guarantee a dialogical posture. However, giving them feedback is just not enough. As some Brazilian research studies have shown (Chimentão, 2016; Janievski, 2012), after making the analysis available and asking participants to respond, the researchers ought to take those comments into consideration, such as explaining participants' doubts (Reis \& Egido, in press), reviewing and rewriting some parts of the analysis based on their comments (Jasnievski, 2012), and so on.

\section{Conclusion}

This prescriptive study aimed at understanding which ethical procedures were taken in international studies. In order to do so, we analysed 15 investigations related to (Critical) Applied Linguistics (Pennycook, 2001). We relied on the main research topics discussed by Brazilian researchers to analyse the data. In conclusion, we observed that most of the topics that came out in our theoretical framework were also covered in the research works analysed. However, the social relevance mentioned by Brazilian researchers was not so clear in the papers that were part of our data. Thus, we believe that the Brazilian researchers have been gone further than some of the articles analysed.

We concluded that some researchers could have adopted other important ethical procedures, but we agree that each investigation has its specifics traits. We hope this work will be food for thought for other researchers, then we may be constantly wondering about our practice. In other words, some researchers have considered the 
participants and their conditions despite forgetting their boarder social context somehow. In short, we do need to be aware of participants' lives once it influences on their thoughts and acts (Pennycook, 2001).

\section{References}

Abasi, A. R., \& Taylor, M. C. (2007). Tackling the issues and challenges of using video data in adult literacy research. Australian Journal of Adult Learning, 47(2), 289-307.

Abrams, Z. I. (2005). Asynchronous CMC, collaboration and the development of critical thinking in a graduate seminar in Applied Linguistics. Canadian Journal of Learning and Technology, 31(2).

Angel, L. A., \& Simpson, M. D. (2007). Report of best practice: Development of an ethics manual as an integral component of undergraduate curriculum and application for graduates and practitioners. Journal of Learning Design, 2(1), 1-13.

Arnett, K., \& Mady, C. (2010). A critically conscious examination of special education within FSL and its relevance to FSL teacher education programs. Canadian Journal of Applied Linguistics/Revue canadienne de linguistique appliquee, 13(1), 19-36.

Cameron, D., Frazer, E., Harvey, P., Rampton, M. B. H., \& Richardson, K. (1994). The relations between researcher and researched: Ethics, advocacy, and empowerment. In D. Graddol, J. Maybin, and B. Stierer (Eds.), Researching language and literacy in social context (pp. 18-25). UK: The Open University.

Celani, M. A. A. (2005). Questões de ética em linguística aplicada (Ethical questions in Applied Linguistics). Linguagem \& Ensino, $8(1), 101-122$.

Chimentão, L. K. (2016). Entre quatro binários: um estudo sobre desenvolvimento profissional docente (Within four binaries: A study on teacher professional development) (Doctorate dissertation, State University of Londrina, Londrina, Brazil).

Christians, C. G. (2005). Ethics and politics in qualitative research. In N. K. Denzin and Y. Lincoln (Eds.), Handbook of qualitative research (3rd ed., pp. 141-162). Thousand Oaks, C.A.: Sage Publications.

Davari, H., Iranmehr, A., \& Erfani, S. M. (2012). A survey on the Iranian ELT community's attitudes to critical pedagogy. English Language Teaching, 5(2), 101-111.

Derrington, M. L., \& Larsen, D. (2009). Student generated case studies: Addressing the standard of ethical leadership. International Journal of Educational Leadership Preparation, 4(2), 1-5.

Egido, A. A., \& Reis, S. (2015). Ethics in research on critical Reading and critical Literacy. Revista brasileira de iniciação científica, 2(3), $75-88$.

Ekahitanond, V. (2014). Students' perception and behavior of academic integrity: A case study of a writing forum activity. Turkish Online Journal of Distance Education, 15(4), 150-161.

Fong, E. H., \& Tanaka, S. (2013). Multicultural alliance of behavior analysis standards for cultural competence in behavior analysis. International Journal of Behavioral Consultation and Therapy, 8(2), 17-19.

Goldacre, L., Bolt, S., \& Lambiris, M. (2013). Designed for learning: A case study in rethinking teaching and learning for a large first year class. Journal of the Scholarship of Teaching and Learning, 13(1), 24-44.

Green, D., Lindemann, I., Marshall, K., \& Wilkinson, G. (2005) Student perceptions of a trial of electronic text matching software: A preliminary investigation. Journal of University Teaching and Learning Practice, 2(3), 26-36.

Guardado, M. (2012). Toward a critical multilingualism in Canadian classrooms: Making local inroads into a cosmopolitan identity. TESL Canada Journal, 30(1), 151-165.

Hodge, K. A., \& Lear, J. L. (2011). Employment skills for 21 st century workplace: The gap between faculty and student perceptions. Journal of Career and Technical Education, 26(2), 28-41.

Howie, M. (2008). Embracing the other within: Dialogical ethics, resistance and professional advocacy in English teaching. English Teaching: Practice and Critique, 7(1), 103-118.

Jasnievski, C. C. (2012). Insatisfação e mudança: identidades sobre o real e o ideal nas bases de conhecimento do professor (Dissatisfaction and changes: Identities about the real and the ideal in the knowledge base of the teacher) (Master thesis, State University of Londrina, Londrina, Brazil).

Jin, Y. (2011). Fundamental concerns in high-stakes language testing: The case of the college English test. Journal of Pan-Pacific Association of Applied Linguistics, 15(2), 71-83.

Khan, I. A. (2011). The teacher of English: Pedagogic relevance in Saudi Arabia. English Language Teaching, 4(2), 112-120.

Kim, I. (2008). The "Becoming-Philosophy" as a foreign language: Rereading Deleuze and Derrida. Journal of Pan-Pacific Association of Applied Linguistics, 12(1), 29-46. 
Koulouriotis, J. (2011). Ethical considerations in conducting research with non-native speakers of English. TESL Canada Journal, 28(5), 1-15.

Lee, E. (2011). Ethical issues in addressing inequity in/through ESL research. TESL Canada Journal, 28(5), 31-52.

Loi, C. X. A., \& McDermott, R. J. (2010). Conducting program evaluation with Hispanics in rural settings: Ethical issues and evaluation challenges. American Journal of Health Education, 41(4), 252-256.

Macpherson, S., Kouritzin, S., \& Kim, S. (2005). Profits or professionalism: Issues facing the professionalization of TESL in Canada. College Quarterly, 8(2), 1-24.

Mello, H. (2010). Formação cidadã: a produção do conhecimento via parceria universidade-escola (Citizen education: The production of knowledge through university and school cooperation). In T. Gimenez and M. C. G. Monteiro (Eds.), Formação de professores de línguas na América Latina e transformação social (Education of language teachers in Latin America and social transformation) (pp. 93-108). Campinas: Pontes.

Menezes de Souza, L. M. T. (2011). O professor de inglês e os letramentos no século XXI: métodos ou ética? (The English teacher and the literacies of 21 st century: Methods or ethics?). In C. M. Jordão, J. Z. Martinez, and R. C. Halu (Eds.), Formação "desformatada" práticas com professores de Lingua Inglesa ("Unformatted" education: practices with English teachers) (pp. 279-303). Campinas: Parábola.

Miller, I. K. (2010). Construindo parcerias universidade-escola: caminhos éticos e questões crítico-reflexivas (Building partnerships between university and school: Ethical possibilities and critical-reflective questions). In T. Gimenez and M. C. G. Monteiro (Eds.), Formação de professores de línguas na América Latina e transformação social (Education of language teachers in Latin America and social transformation) (pp. 109-129). Campinas: Pontes.

Miller, I. K. (2013). Formação de professores de línguas: da eficiência à reflexão crítica e ética. In L. P. Moita Lopes (Ed.), Linguística Aplicada na Modernidade Recente (Applied linguistics in late modernity) (pp. 99-121). São Paulo: Parábola.

Moita Lopes, L. P. (2006). Lingüística Aplicada e a vida contemporânea: problematização dos construtos que têm orientado a pesquisa (Applied linguistics and the contemporary life: Problematizing the constructs of research). In L. P. Moita Lopes (Ed.), Por uma Lingüistica Aplicada indisciplinar (By an indisciplinary Applied Linguistics' field) (pp. 85-107). São Paulo: Parábola.

Mossman, T. (2012). They're different from who i am: Making relevant identities in the middle through talk-in-interaction. TESL Canada Journal, 29(6), 103-123.

Paiva, V. M. O. (2005). Reflexões sobre ética e pesquisa (Reflections about ethics and research). Revista Brasileira de Linguística Aplicada, 1, 43-61.

Pennycook, A. (2001). Critical applied linguistics: A critical introduction. Mahawah: Lawerence Erbaum Associates.

Reis, S., \& Egido, A. A. (in press). Ontologia, Epistemologia e Ética como determinantes metodológicos em Estudos da Linguagem (Ontolody, epistemology and ethics as methodological guides in language studies). In S. Reis (Ed.), História, politicas e ética na área profissional da linguagem (History, policies and ethics in the professional field of language). Londrina: Eduel.

Reis, S., Egido, A. A., Silva, J. O., Coradim, J. N., \& D’Almas, J. (2016). Critical applied linguistics matters. In International Congress of Critical Applied Linguistics (pp. 1086-1105), Brasília, DF, Brasil.

Sánchez, W. (2007). On the nature of applied linguistics: Theory and practice relationships from a critical perspective. GIST Education and Learning Research Journal, 1, 98-114.

Scalia, J. I., \& Scaila, L. (2011). Ideological critique and ethical leadership. Philosophical Studies in Education, 42, 55-64.

Shinn, G. C., Briers, G., \& Baker, M. (2008). Forecasting doctoral-level content in agricultural education: Viewpoints of engaged scholars in the United States. Journal of Agricultural Education, 49(1), 121-131.

Swain, M., \& Lapkin, S. (2011). Languaging as agent and constituent of cognitive change in an older adult: An example. Canadian Journal of Applied Linguistics/Revue canadienne de linguistique appliquee, 14(1), 104-117.

Toprak, E., Ozkanal, B., Aydin, S., \& Kaya, S. (2010). Ethics in e-learning. Turkish Online Journal of Educational Technology, 9(2), 78-86.

Welch, K. C., Hieb, J., \& Graham, J. (2015). A systematic approach to teaching critical thinking skills to electrical and computer engineering undergraduates. American Journal of Engineering Education, 6(2), 113-123.

Wernicke, M. (2010). Study abroad as professional development for FSL teachers. Canadian Journal of Applied Linguistics/Revue canadienne de linguistique appliquee, 13(1), 4-18.

White, B., \& Haberling, J. (2006). The case for studying character(s) in the literatute classroom. Journal of Language and Literacy Education, 2(2), 1-21.

Zhao, G. (2014). Mead, Habermas, and Levinas: Cultivating subjectivity in education for democracy. Philosophical Studies in Education, 45, 113-12. 